\title{
Enhanced expression of peroxisome proliferator-activated receptor gamma in epithelial ovarian carcinoma
}

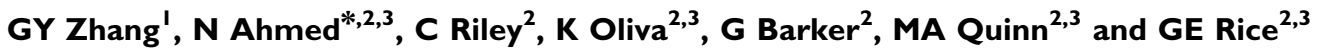 \\ 'Department of Obstetrics and Gynaecology, Qilu Hospital of Shandong University, 107 Wenhuaxi Road, Jinan 2500 I2, PR China; ${ }^{2}$ Gynaecological \\ Cancer Research Centre, The Royal Women's Hospital, 132 Grattan Street, Carlton, Victoria 3053, Australia; ${ }^{3}$ Department of Obstetrics and \\ Gynaecology, The University of Melbourne, Victoria, Australia
}

\begin{abstract}
The peroxisome proliferator-activated receptors (PPARs) belong to a subclass of nuclear hormone receptor that executes important cellular transcriptional functions. Previous studies have demonstrated the expression of PPAR $\gamma$ in several tumours including colon, breast, bladder, prostate, lung and stomach. This study demonstrates the relative expression of PPAR $\gamma$ in normal ovaries and different pathological grades of ovarian tumours of serous, mucinous, endometrioid, clear cell and mixed subtypes. A total of 56 ovarian specimens including 10 normal, eight benign, 10 borderline, seven grade I, nine grade 2 and 12 grade 3 were analysed using immunohistochemistry. Immunoreactive PPAR $\gamma$ was not expressed in normal ovaries. Out of eight benign and 10 borderline tumours, only one tumour in each group showed weak cytoplasmic PPAR $\gamma$ expression. In contrast, 26 out of 28 carcinomas studied were positive for PPAR $\gamma$ expression with staining confined to cytoplasmic and nuclear regions. An altered staining pattern of PPAR $\gamma$ was observed in high-grade ovarian tumours with PPAR $\gamma$ being mostly localized in the nuclei with little cytoplasmic immunoreactivity. On the other hand, predominant cytoplasmic staining was observed in lower-grade tumours. Significantly increased PPAR $\gamma$ immunoreactivity was observed in malignant ovarian tumours (grade I, 2 and 3) compared to benign and borderline tumours $\left(\chi^{2}=48.80, P<0.001\right)$. Western blot analyses showed significant elevation in the expression of immunoreactive PPAR $\gamma$ in grade 3 ovarian tumours compared with that of normal ovaries and benign ovarian tumours $(P<0.01)$. These findings suggest an involvement of PPAR $\gamma$ in the onset and development of ovarian carcinoma and provide an insight into the regulation of this molecule in the progression of the disease.
\end{abstract}

British Journal of Cancer (2005) 92, I13-119. doi:10.1038/sj.bjc.6602244 www.bjcancer.com

Published online 7 December 2004

(c) 2005 Cancer Research UK

Keywords: peroxisome proliferator-activated receptor; ovarian cancer; immunohistochemistry; nuclear and cytoplasmic staining

Epithelial ovarian cancer is the leading cause of death from gynaecologic malignancies. As ovarian cancer produces few specific symptoms in the early stage, most women present with advanced stage disease where the prognosis is poor (Jacobs and Menon, 2004). Greater than $90 \%$ of epithelial ovarian cancer arises from the transformation of ovarian surface epithelium (Choi and Auersperg, 2003). Hence, comparison between the protein expression profile of normal and transformed ovaries is important to identify and understand the molecules involved in the onset and progression of the disease.

The peroxisome proliferator-activated receptors (PPARs) comprise an important subfamily of the nuclear hormone receptor superfamily. Three isoforms have been identified, $\operatorname{PPAR} \alpha, \operatorname{PPAR} \beta$ and PPAR $\gamma$. Each exhibits distinct patterns of tissue distribution and ligand specificity (Kersten et al, 2000). They share common structural features, which include an amino-terminal modulatory domain, a DNA-binding domain and a carboxyl-terminal ligand-

\footnotetext{
* Correspondence: Dr N Ahmed, Gynaecological Cancer Research Centre, The Royal Women's Hospital, 132 Grattan Street, Carlton, Victoria 3053, Australia; E-mail: nuzhata@unimelb.edu.au

Received 20 June 2004; revised 20 September 2004; accepted 28 September 2004; published online 7 December 2004
}

binding domain (Moras and Gronemeyer, 1998). PPAR $\alpha$ is present in high levels in the kidney, heart, muscle, liver, brown adipose tissue and gut (Kliewer et al, 1994), whereas $\operatorname{PPAR} \beta$ is ubiquitously expressed throughout the body (Kliewer et al, 1994). PPAR $\gamma$ is highly expressed in adipose tissue, and is also present in other tissues including the muscle, liver, heart, adrenal gland, spleen and placenta (Asami-Miyagishi et al, 2004; Feingold et al, 2004).

The PPARs are ligand-dependent transcription factors that regulate target gene expression by binding to specific peroxisome proliferator response elements (PPREs) in enhancer sites of target genes (Berger and Moller, 2002). Each receptor binds its PPREs as a heterodimer with a retinoid $\mathrm{X}$ receptor. Upon ligand activation, conformational rearrangement of PPAR $\gamma$ expresses transcriptional coactivator binding sites. Recruitment of coactivators involves transcription of genes implicated in the regulation of cell differentiation and activation pathways (Berger and Moller, 2002).

In cancer biology, PPAR $\gamma$ is the most intensively studied PPAR isoform. It is expressed in high levels in different cancer including colon (Bull, 2003), breast (Jiang et al, 2003), bladder (Yoshimura et al, 2003), prostate (Smith and Kantoff, 2002), head and neck (Jaeckel et al, 2001), cervical (Han et al, 2003) and endometrial cancer (Tong et al, 2000). Recent studies have demonstrated that ligand activation of PPAR $\gamma$ receptor is involved in adipocyte (Seo et al, 2004) and tumour cell differentiation (Gauthier et al, 2003). 
In colon cancer, ligand activation of $\operatorname{PPAR} \gamma$-mediated differentiation of certain colon cancer cells results in the upregulation of tumour suppressor genes caveolin 1 and 2 (Burgermeister et al, 2003) and repression of cyclin D1 expression (Wang et al, 2003). Similarly, in vitro studies in prostate cancer cells, which express fairly abundant PPAR $\gamma$, can result in the differentiation of prostate cancer cells and downregulation of androgen-stimulated PSA production (Hisatake et al, 2000). These findings have potentially important functional implication in the context of cancer cell differentiation therapy and multidrug resistance. Recently, Her2 has been shown to regulate PPAR expression (Yang et al, 2003). The ligands for PPAR $\gamma$ have been shown to increase the expression of BRCA 1 protein in human breast cancer cells (Pignatelli et al, 2003), indicating that $\operatorname{PPAR} \gamma$ plays a crucial role in BRCA1 regulatory pathways involved in the pathogenesis of breast and sporadic ovarian cancer.

To our knowledge, a role for $\operatorname{PPAR} \gamma$ in ovarian cancer development or function has not been described. In this study, we evaluated immunoreactive $\operatorname{PPAR} \gamma$ protein expression in different pathological grades and subtypes of human epithelial ovarian tumours. We show that ovarian tumours express PPAR $\gamma$ and that expression is significantly higher in malignant tumours compared to benign tumours and normal ovaries. We also demonstrate that PPAR $\gamma$ expression pattern alters in high-grade ovarian tumours, implicating an important role for PPAR $\gamma$ in the progression of ovarian malignancy.

\section{MATERIALS AND METHODS}

\section{Antibody and reagents}

Mouse monoclonal and rabbit polyclonal antibodies against PPAR $\gamma$ were obtained from Santa Cruz Biotechnology Inc. (Santa Cruz, CA, USA). Mouse IgG1 was obtained from Sigma (Sigma, St Louis, MO, USA). Immunoperoxidase secondary detection system was obtained from Chemicon International (Temecula, USA). ECL Western blotting detection reagents and analysis system were supplied by Amersham Biosciences (Amersham, UK).

\section{Immunohistochemistry}

The study was approved by the Research and Human Ethics Committee (HEC\#02/30) of the Royal Women's Hospital, Melbourne, Australia. Human ovarian tumour tissues were collected at the time of surgical cytoreduction with the informed consent of the patients. Patient information is presented in Table 1. Normal ovaries for control comparison were collected from patients undergoing surgery as a result of suspicious ultrasound, from prophylactic oophorectomy specimens. The pathology diagnosis and tumour grade was evaluated by two staff pathologists in the Department of Pathology, the Royal Women's Hospital, Melbourne, Australia. The classification of the tumours was performed as part of the clinical diagnosis according to the method described by Silverberg (2000). Surgically removed samples were fixed in $10 \%$ formalin and embedded in paraffin. Tissues for Western blot were snap frozen in liquid nitrogen and stored at $-80^{\circ} \mathrm{C}$ until needed.

Paraffin-embedded ovarian tissues were cut at $4 \mu \mathrm{m}$ thickness and deparaffinised with xylene and rehydrated using graded ethanol. After microwave antigen retrieval in citrate buffer, $\mathrm{pH} 6.0$, the sections were held in Tris buffer solution (TBS, $100 \mathrm{~mm}, \mathrm{pH}$ 7.6). Endogenous peroxidase activity was inactivated using $3 \%$ hydrogen peroxide in methanol and endogenous biotin activity was blocked by a sequence of diluted egg white (5\% in distilled water) and skimmed milk powder (5\% in distilled water), all for $10 \mathrm{~min}$ each. The sections were incubated in mouse monoclonal antibody against $\operatorname{PPAR} \gamma$ ( $1 / 400$ in $1 \%$ BSA in TBS) overnight at
Table I Description of ovarian cancer patients participating in the study

\begin{tabular}{|c|c|c|c|c|}
\hline Case no. & $\begin{array}{c}\text { Histological } \\
\text { grade }\end{array}$ & $\begin{array}{l}\text { Clinical } \\
\text { stage }\end{array}$ & $\begin{array}{l}\text { Tumour } \\
\text { subtype }\end{array}$ & $\begin{array}{c}\text { CAI } 25 \\
\left(\mathrm{Uml}^{-1}\right)\end{array}$ \\
\hline 6 & 1 & $\mathrm{Ia}$ & Endometrioid & 773 \\
\hline 64 & 1 & $\mathrm{Ib}$ & Endometrioid & 786 \\
\hline 83 & 1 & IC & Endometrioid & 126 \\
\hline 106 & 1 & $3 c$ & Mixed & 93 \\
\hline 164 & I & Ib & Endometrioid & 636 \\
\hline 190 & 1 & $\mathrm{la}$ & Mucinous & 25 \\
\hline 198 & I & $2 c$ & Endometrioid & 55 \\
\hline 32 & 2 & $\mathrm{la}$ & Endometrioid & 302 \\
\hline 35 & 2 & $3 c$ & Serous & 1200 \\
\hline 46 & 2 & 4 & Serous & 3457 \\
\hline 49 & 2 & $3 c$ & Serous & 900 \\
\hline 110 & 2 & $3 c$ & Serous & 1719 \\
\hline 121 & 2 & $3 c$ & Serous & 3471 \\
\hline 123 & 2 & $3 b$ & Mixed & 106 \\
\hline 129 & 2 & $3 c$ & Mixed & 3823 \\
\hline 161 & 2 & Ic & Mixed & 698 \\
\hline 2 & 3 & $3 c$ & Serous & 647 \\
\hline 3 & 3 & $3 c$ & Serous & 513 \\
\hline 44 & 3 & $2 b$ & Endometrioid & 165 \\
\hline 85 & 3 & $\mathrm{la}$ & Serous & 147 \\
\hline 88 & 3 & $3 c$ & Serous & 883 \\
\hline 90 & 3 & $3 c$ & Endometrioid & 659 \\
\hline 96 & 3 & $3 c$ & Serous & 137 \\
\hline 108 & 3 & $3 c$ & Serous & 61 \\
\hline 143 & 3 & 4 & Clear cell & 507 \\
\hline 146 & 3 & 4 & Serous & 2463 \\
\hline 153 & 3 & 4 & Serous & 985 \\
\hline 158 & 3 & $3 c$ & Serous & 287 \\
\hline
\end{tabular}

$4^{\circ} \mathrm{C}$. Antibody binding was amplified using biotin and streptavidin HRP for $10 \mathrm{~min}$ each and the complex was visualised using diaminobenzidine. The nuclei were lightly stained with Mayer's haematoxylin and the sections were mounted and cover slipped. An isotype $\operatorname{IgG}_{1}$ matched diluted was substituted for the antibody as negative control.

Sections were assessed microscopically for positive staining by two experienced observers. For each specimen, the positive staining extent was scored as five grades, namely, $0(\leqslant 10 \%), 1$ $(\geqslant 11-25 \%), 2(\geqslant 26-50 \%), 3(\geqslant 51-75 \%), 4(\geqslant 76-90 \%)$ and 5 $(\geqslant 91-100 \%)$ (Armes et al, 1999). The intensity was classified into four grades: no staining, negative $(-)$; pale brown, weak $(+)$; brown, moderate $(++)$ and dark brown, strong $(+++)$. Parallel paraffin-embedded sections were stained with haematoxylin and eosin to confirm the pathologic diagnosis simultaneously.

\section{Western blot}

Preparation of ovarian tissue homogenate was performed as described previously (Ahmed et al, 2004). Each frozen ovarian specimen $(100 \mathrm{mg})$ was cut into several small pieces about $3 \mathrm{~mm}$ in size. Then, the specimen was homogenized in Tris-HCl buffer ( $10 \mathrm{~mm}$ Tris, $150 \mathrm{~mm} \mathrm{NaCl}, 2 \mathrm{~mm}$ EDTA, $2 \mathrm{~mm}$ dithiothreitol, $1 \mathrm{~mm}$ orthovanadate, $1 \mathrm{~mm}$ phenylmethylsulphonyl fluoride, $5 \mu \mathrm{g} \mathrm{ml}^{-1}$ aprotonin, $\mathrm{pH}$ 7.0) by repeated uniform strokes (approximately 6). The samples were centrifuged at $10000 \mathrm{~g}$ for $20 \mathrm{~min}$. The supernatant was collected and relative protein concentration was determined using Bio-Rad Protein Assay Reagent following the manufacturer's instruction. Ovarian homogenate containing equal amounts $(10 \mu \mathrm{g})$ of protein were separated by electrophoresis on $10 \%$ sodium dodecyl sulphate (SDS) - polyacrylamide gels under nonreducing condition and transferred to nitrocellulose membranes. The membranes were probed with rabbit polyclonal anti$\operatorname{PPAR} \gamma$ (diluted 1:400 in 3\% skim milk in TBST) followed by 
peroxidase-labelled donkey anti-rabbit secondary antibody $(1: 2500)$ and visualised by the ECL (Amersham, UK) detection system according to the manufacturer's instruction.

\section{Statistical analysis}

The extent and intensity of immunohistochemical staining between benign, borderline and high-grade ovarian tumours was determined by $\chi^{2}$ test. The association between the optical density

Table 2 Extent and intensity of PPAR $\gamma$ expression in normal ovaries and tumour tissues

\begin{tabular}{lccc}
\hline Histology & $\begin{array}{c}\text { Total } \\
\text { number of } \\
\text { tissues }\end{array}$ & $\begin{array}{c}\text { Extent of staining } \\
\text { (number of } \\
\text { tissues) }\end{array}$ & $\begin{array}{c}\text { Intensity of } \\
\text { staining (number } \\
\text { of tissues) }\end{array}$ \\
\hline Normal & 10 & $0(10)$ & $-(10)$ \\
Benign & 8 & $0(7), I(1)$ & $-(7),+(1)$ \\
Borderline & 10 & $0(9), I(1)$ & $-(9),+(1)$ \\
Grade I & 7 & $0(0), I(6), 2(0), 3(1)$ & $-(0),+(3),++(4)$ \\
Grade 2 & 9 & $0(1), I(5), 2(1), 3(2)$ & $-(1),+(5),++(3)$ \\
Grade 3 & 12 & $0(1), I(5), 2(1), 3(5)$ & $-(1),+(7),++(4)$ \\
Total & 56 & 56 & 56 \\
\hline
\end{tabular}

PPAR $=$ peroxisome proliferator-activated receptor. Extent of PPAR $\gamma$ expression was scored as $0(\leqslant 10 \%), 1(\geqslant 11-25 \%), 2(\geqslant 26-50 \%), 3(\geqslant 51-75 \%), 4(\geqslant 76-$ $90 \%)$ and $5(\geqslant 91-100 \%)$ immunoreactivity. Values within parentheses indicate number of tissues in each category. The extent of staining was significantly different in grade I, 2 and 3 tumours compared to benign and borderline tumours $\left(\chi^{2}=48.80\right.$; $P<0.00$ I). The intensity of staining was scored as negative $(-)$, weak $(+)$, moderate $(++)$ and strong $(+++)$ staining. The values within parentheses indicate the number of tissues in each category. The intensity of staining was significantly different in grade I, 2 and 3 tumours compared to benign and borderline tumours $\left(\chi^{2}=43.93\right.$; $P<0.001$ ).
(OD) of PPAR $\gamma$ bands determined by Western blotting in benign tumours compared to that of high-grade ovarian tumours was assessed by Student's $t$-test.

\section{RESULTS}

\section{Immunohistochemical staining of PPAR $\gamma$ in ovarian tumour tissues}

Immunohistochemical expression of PPAR $\gamma$ in epithelial ovarian tumours is described in Table 2. No immunoreactivity of PPAR $\gamma$ was observed in normal ovarian tissues (Figure 1C). Among eight benign and 10 borderline ovarian tumours, weak PPAR $\gamma$ expression was present in only one tumour in each group (Figure $2 \mathrm{~A}$ ). Seven cases of grade 1 ovarian tumours were studied. Four of these showed weak staining and moderate staining was observed in three cases. Both cytoplasmic and nuclear staining was observed (Figure 2B), the distribution being approximately $60 \%$ cytoplasmic and $40 \%$ nuclear.

Eight out of nine grade 2 tumours studied were positive for PPAR $\gamma$ and the expression varied from a score of 1 to 3 with increased demonstration of nuclear staining (Figure 2C). Nuclear staining of infiltrating macrophages was observed in one case. In all, 12 grade 3 ovarian tumours were studied and 11 of these were positive. The intensity of $\operatorname{PPAR} \gamma$ staining varied but was predominantly judged to be moderate $(++)$ (Figures 1D and $2 \mathrm{D}, \mathrm{E})$. In grade 2 and 3 tumours, staining was predominantly nuclear. Cytoplasmic staining in higher grades (grades 2 and 3) represented approximately $20 \%$ of total staining.

Overall, the immunoreactive $\operatorname{PPAR} \gamma$ was present in all grades of ovarian tumours. The extent of overall staining was significantly higher in malignant ovarian tumours (grades 1, 2 and 3) compared with benign and borderline tumours $\left(\chi^{2}=48.80, P<0.001\right)$ (Table 2). PPAR $\gamma$ staining in ovarian tumours was mainly localised to the cytoplasm or nuclei of tumour cells. Nuclear staining
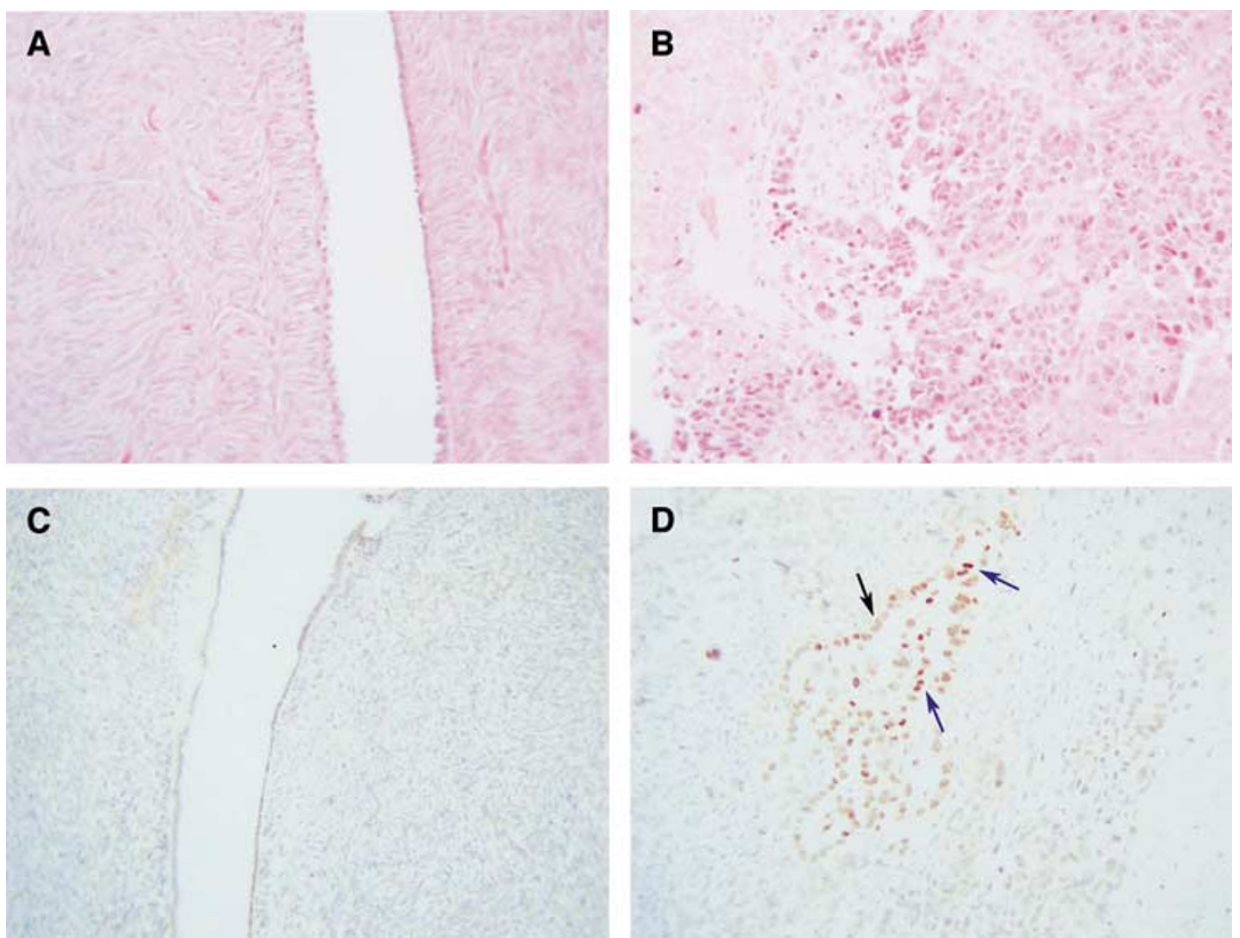

Figure I (A and B) Haematoxylin and eosin staining of $(\mathbf{A})$ normal ovary,

B) grade 3 serous tumour. PPAR $\gamma$ staining of the same (C) normal ovary (D) and grade 3 serous ovary. Blue arrows indicate nuclear PPAR $\gamma$ staining, while black indicates cytoplasmic staining. 

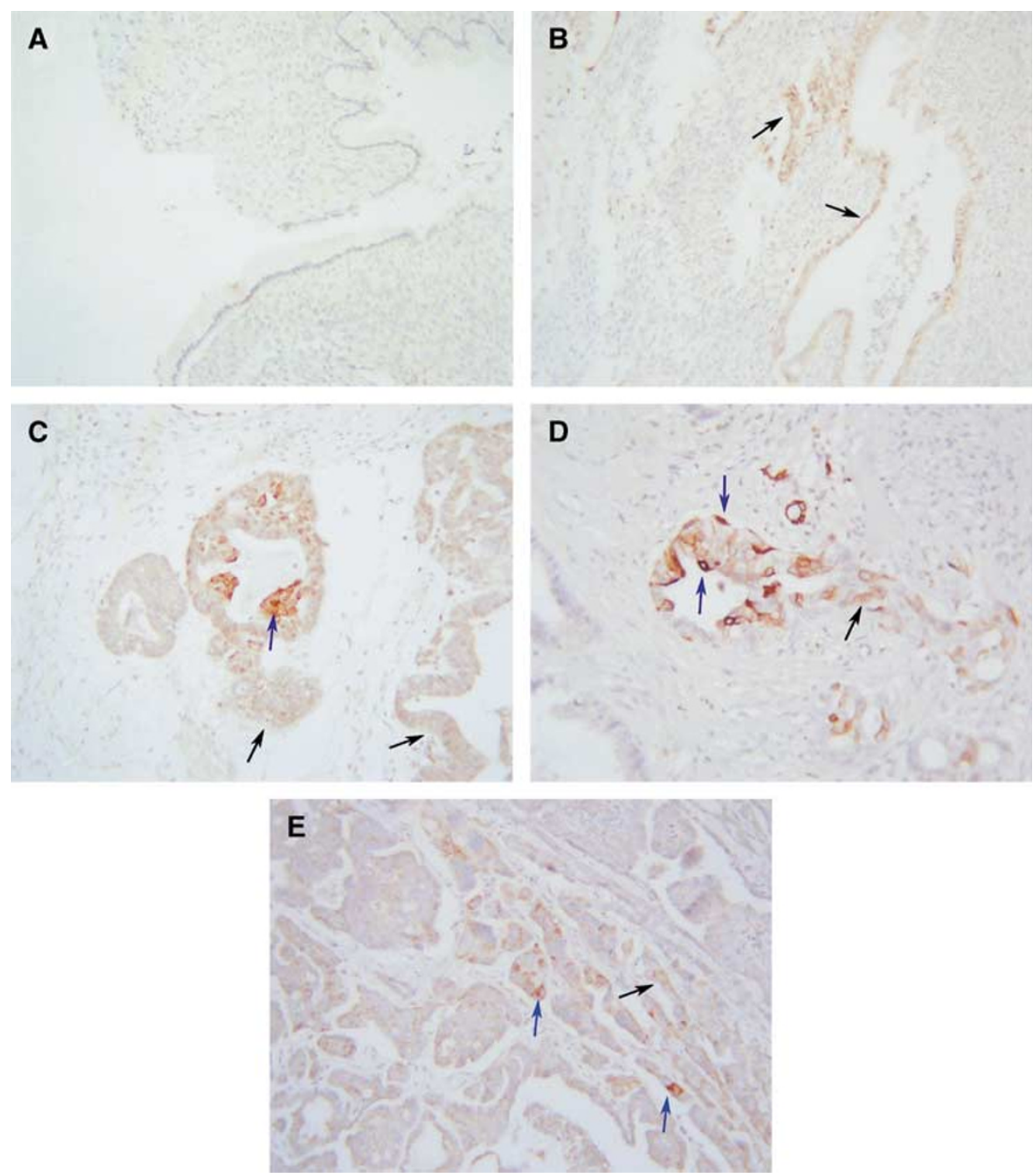

Figure 2 PPAR $\gamma$ staining of $(\mathbf{A})$ benign mucinous tumour, $(\mathbf{B})$ grade I mucinous tumour, $(\mathbf{C})$ grade 2 endometrioid tumour, tumours and $(\mathbf{E})$ grade 3 serous tumour. Arrows indicate nuclear (blue) and cytoplasmic (black) PPAR $\gamma$ staining.

increased significantly with the grade of the tumours ( $80 \%$ in grade 3 compared to $40 \%$ in grade 1 ). Tumour stroma or endothelial cells lining the blood vessels were negative for $\operatorname{PAAR} \gamma$ immunoreactivity. The intensity of $\operatorname{PPAR} \gamma$ staining was also significantly higher in malignant tumours compared with benign and borderline tumours $\left(\chi^{2}=43.93, P<0.001\right)$ (Table 2$)$. No statistical difference in the extent or intensity of staining was observed between the different grades of tumours (grades 1,2 and 3$)\left(\chi^{2}=4.29, P=0.6363\right.$; $\chi^{2}=1.68, P=0.79$ ) (Table 2).

\section{Expression of PPAR $y$ in ovarian tumour tissues using Western blot analysis}

The expression of PPAR $\gamma$ in human ovarian tumour tissues was also evaluated by Western blot analyses (Figure 3 ). The expression of $\operatorname{PPAR} \gamma$ in ovarian tumour tissues was significantly higher than in normal ovaries and benign ovarian tumours $(P<0.01)$ (Figure 3A). However, no difference in the expression of PPAR $\gamma$ in normal ovaries and benign ovarian tumours was demonstrated $(P>0.05)$ (Figure 3C).

\section{DISCUSSION}

The sustainability of a malignant tumour requires multiple cellular events by which the cancer cells acquire growth factor independence, escape cellular apoptosis mechanisms, create a selfsustaining environment and escape the neighbouring barriers by migrating and colonising to a distant site (Hanahan and Weinberg, 2000). These events require the expression/overexpression and activation of molecules not generally requisite for normal cellular functions. The initial indication that the PPARs are involved in the aetiology of cancer was the isolation of $\operatorname{PPAR} \alpha$ as the mediator of the tumour-promoting effect of peroxisome proliferators, compounds that cause heptocellular carcinoma in rodents (Corton et al, 2000). PPAR $\alpha$ has been shown to be expressed in colon tumours and overexpressed in breast and prostate tumours (Collett et al, 2000; Roberts-Thomson and Snyderwine, 2000). PPAR $\beta$ levels are also elevated in colon and head and neck cancer (Gupta et al, 2000; Jaeckel et al, 2001) and the absence of $\operatorname{PPAR} \beta$ reduces tumour growth in colon cancer (Park et al, 2001). Although PPAR $\gamma$ is expressed at low levels in normal colonic and breast ductal epithelium, it is significantly increased in breast and prostate 
A

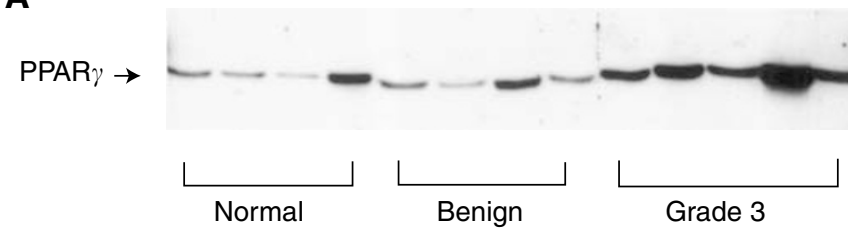

B

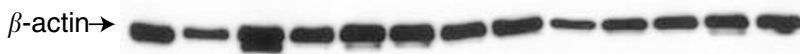

C

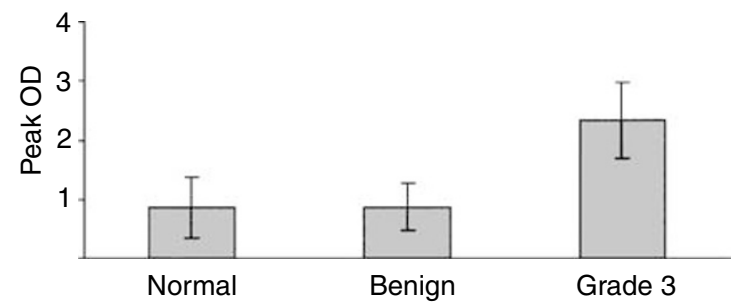

Figure 3 Western blot analyses of PPAR $\gamma$ expression in normal ovary, benign and grade 3 ovarian tumours. (A) Western blot was carried out as described in the Material and Methods section. A total of $10 \mu \mathrm{g}$ of protein was loaded in a total volume of $20 \mu \mathrm{l}$ in each lane. The results are representative of one experiment repeated three times. (B) $\beta$-actin staining of the same samples loaded in same concentration to ensure equal protein loading. (C) Quantification of PPAR $\gamma$ expression was performed by densitometry and expressed as mean peak OD \pm s.e.m. of the number of samples described in each group.

carcinoma. The expression of this receptor has not been reported in ovarian carcinoma but has been shown in normal ovaries (Lambe and Tugwood, 1996). In this study, we report the expression of PPAR $\gamma$ in different pathological grades and subtypes of ovarian carcinoma and discuss its possible function with the progression of the disease.

We report for the first time that ovarian tumours express $\operatorname{PPAR} \gamma$. Weak to moderate expression of $\operatorname{PPAR} \gamma$ by immunohistochemistry was observed in almost all ovarian tumours studied. As shown in Table 2 and Figure 1, immunohistochemical staining showed no PPAR $\gamma$ expression in normal ovarian tissues. Out of eight benign and 10 borderline tumours, only one in each group stained positive for PPAR $\gamma$ expression. Weak to moderate staining was observed in grade 1 ovarian tumours (Figure $2 \mathrm{~B}$ ), and the staining was localised to both cytoplasmic and nuclear areas of the cells. Compared to benign and borderline tumours, the extent of staining was, however, significantly increased in grade 3 ovarian tumours, with immunoreactivity for PPAR $\gamma$ being mostly present in the nuclear region (Figures 1 and 2). Western blotting analyses demonstrated significant enhancement in the expression of PPAR $\gamma$ in grade 3 ovarian tumours compared to benign ovarian tumours and normal ovaries (Figure 3). The basal expression of PPAR $\gamma$ in normal ovarian tissues and benign ovarian tumours may have been attributed by the increased immunosensitivity of Western blotting technique compared to immunohistochemistry.

The results from our study are consistent with those of other studies performed in other cancers. Very weak immunohistochemical staining of $\operatorname{PPAR} \gamma$ was shown in benign prostatic hyperplasia and normal prostate tissues, whereas significant enhancement in the expression of immunoreactive PPAR $\gamma$ was observed in malignant prostate tissues (Park et al, 2001). PPAR $\gamma$ expression was shown to be higher in high-grade bladder cancer compared to low-grade cancer (Yoshimura et al, 2003). Irrespec- tive of the differentiation status of the tumour, strong expression of immunoreactive PPAR $\gamma$ was observed in surgically resected human gastric cancer tissues (Sato et al, 2000).

In contrast, in some cases of cancer, the expression of PPAR $\gamma$ decreases with the histological grade of the tumour. In full-term normal placenta, $\operatorname{PPAR} \gamma$ is strongly expressed in the nuclei of the syncytiotrophoblast, extravillous cytotrophoblast of cell islands and cell columns, whereas in choriocarcinoma, only a few trophoblastic cells show weak staining for $\operatorname{PPAR} \gamma$ (Capparuccia et al, 2002). Well-differentiated lung adenocarcinomas present increased frequency for PPAR $\gamma$ expression compared with moderately and poorly differentiated ones (Theocharis et al, 2002). The expression of $\operatorname{PPAR} \gamma$ protein is decreased in oesophageal cancer tissues compared with normal oesophageal squamous epithelium (Terashita et al, 2002). Hence, considering the diversity of human cancer, the expression of PPAR $\gamma$ is possibly dependent on tissue specificity and/or the mutational events (as in the case of colon cancer) (Ikezoe et al, 2001) that are requisite for cancer development.

The growth inhibitory and differentiation roles of PPAR $\gamma$ have been shown in several cancers (Demetri et al, 1999). The immunohistochemical expression of $\operatorname{PPAR} \gamma$ during the progression of ovarian cancer can be related to the growth-promoting role of PPAR $\gamma$ previously shown in certain cancer (Mueller et al, 2000). In the case of thyroid follicular cancer, a chromosomal translocation and fusion of PAX8 gene with PPAR $\gamma$ results in a malignant phenotype, suggesting a link of PPAR $\gamma$ to cancer growth (Dwight et al, 2003). In the Min mouse model of APC deficiency, ligands for $\operatorname{PPAR} \gamma$ can increase colon tumour growth (Lefebvre et al, 1998). In another study, loss of PPAR $\gamma$ was shown not to affect mammary development and propensity for tumour formation but resulted in reduced fertility (Cui et al, 2002). Overall, ligand activation of $\operatorname{PPAR} \gamma$ in tumour models can result in diversified functional outcome (Leung et al, 2004) and a better understanding of the exact role of PPAR $\gamma$ in cancer needs to be determined. In particular, the mechanism of differentiation of cancers is incompletely understood and an insight into this process would undoubtedly lead to new therapeutic targets.

The anti-inflammatory response of PPAR $\gamma$ in association with NF- $\kappa \mathrm{B}$ has recently been identified (Kelly et al, 2004). In addition, $\operatorname{PPAR} \gamma$ ligands have been shown to inhibit transcriptional activation of COX-2 in human epithelial cells (Badawi et al, 2004). In certain cancer cells, ligand activation of PPAR $\gamma$ results in the inhibition of the release of inflammatory cytokines by cancer cells (Leung et al, 2004). These results may help to explain the shuttling of PPAR $\gamma$ expression from the cytoplasm to nucleus with the progression of ovarian carcinoma. As ovarian cancer progresses, tumour cells are more likely to be exposed to inflammatory cytokines secreted by cancer cells themselves and infiltrating leucocytes present in the peritoneum. Whether this increased exposure of ovarian tumour cells to the inflammatory cytokines result in the activation of $\operatorname{PPAR} \gamma$ and subsequent cytoplasmic translocation to the nucleus is yet to be determined.

Taken together, our results indicate that $\operatorname{PPAR} \gamma$ may play a role in the onset and progression of ovarian cancer. Further research need to investigate the prognostic significance of PPAR $\gamma$ expression in ovarian carcinoma and whether therapeutic administration of ligands for this receptor may have clinical potential for the treatment of the disease.

\section{ACKNOWLEDGEMENTS}

We thank the Cancer Council of Victoria, the Rotary Club of Williamstown, Ovcare and Jigsaw Women's Fashion Company and the Jack Brockhoff Foundation, Australia for supporting this work. Dr GY Zhang received a Chinese government scholarship during the course of the study. 


\section{REFERENCES}

Ahmed N, Oliva K, Rice GE, Quinn MA (2004) Cell-free $59 \mathrm{kDa}$ immunoreactive integrin-linked kinase: a novel marker for ovarian carcinoma. Clin Cancer Res 10: 2415-2420

Armes JE, Trute L, White D, Southey MC, Hammet F, Tesoriero A, Hutchins AM, Dite GS, McCredie MR, Giles GG, Hopper JL, Venter DJ (1999) Distinct molecular pathogeneses of early-onset breast cancers in BRCA1 and BRCA2 mutation carriers: a population-based study. Cancer Res 59: $2011-2017$

Asami-Miyagishi R, Iseki S, Usui M, Uchida K, Kubo H, Morita I (2004) Expression and function of PPARgamma in rat placental development Biochem Biophys Res Commun 315: 497 - 501

Badawi AF, Eldeen MB, Liu Y, Ross EA, Badr MZ (2004) Inhibition of rat mammary gland carcinogenesis by simultaneous targeting of cyclooxygenase-2 and peroxisome proliferator-activated receptor gamma. Cancer Res 64: 1181 - 1189

Berger J, Moller DE (2002) The mechanisms of action of PPARs. Annu Rev Med 53: $409-435$

Bull AW (2003) The role of peroxisome proliferator-activated receptor gamma in colon cancer and inflammatory bowel disease. Arch Pathol Lab Med 127: 1121 - 1123

Burgermeister E, Tencer L, Liscovitch M (2003) Peroxisome proliferatoractivated receptor-gamma upregulates caveolin-1 and caveolin-2 expression in human carcinoma cells. Oncogene 22: 3888-3900

Capparuccia L, Marzioni D, Giordano A, Fazioli F, De Nictolis M, Busso N, Todros T, Castellucci M (2002) PPARgamma expression in normal human placenta, hydatidiform mole and choriocarcinoma. Mol Hum Reprod 8: $574-579$

Choi KC, Auersperg N (2003) The ovarian surface epithelium: simple source of a complex disease. Minerva Ginecol 55: 297-314

Collett GP, Betts AM, Johnson MI, Pulimood AB, Cook S, Neal DE, Robson $\mathrm{CN}$ (2000) Peroxisome proliferator-activated receptor alpha is an androgen-responsive gene in human prostate and is highly expressed in prostatic adenocarcinoma. Clin Cancer Res 6: 3241-3248

Corton JC, Lapinskas PJ, Gonzalez FJ (2000) Central role of PPARalpha in the mechanism of action of hepatocarcinogenic peroxisome proliferators. Mutat Res 448: $139-151$

Cui Y, Miyoshi K, Claudio E, Siebenlist UK, Gonzalez FJ, Flaws J, Wagner KU, Hennighausen L (2002) Loss of the peroxisome proliferationactivated receptor gamma (PPARgamma) does not affect mammary development and propensity for tumor formation but leads to reduced fertility. J Biol Chem 277: 17830-17835, Epub 2002 Mar 7

Demetri GD, Fletcher CD, Mueller E, Sarraf P, Naujoks R, Campbell N, Spiegelman BM, Singer S (1999) Induction of solid tumor differentiation by the peroxisome proliferator-activated receptor-gamma ligand troglitazone in patients with liposarcoma. Proc Natl Acad Sci USA 96: $3951-3956$

Dwight T, Thoppe SR, Foukakis T, Lui WO, Wallin G, Hoog A, Frisk T, Larsson C, Zedenius J (2003) Involvement of the PAX8/peroxisome proliferator-activated receptor gamma rearrangement in follicular thyroid tumors. J Clin Endocrinol Metab 88: 4440-4445

Feingold K, Kim MS, Shigenaga J, Moser A, Grunfeld C (2004) Altered expression of nuclear hormone receptors and coactivators in mouse heart during the acute-phase response. Am J Physiol Endocrinol Metab 286: E201 - E207

Gauthier A, Vassiliou G, Benoist F, McPherson R (2003) Adipocyte low density lipoprotein receptor-related protein gene expression and function is regulated by peroxisome proliferator-activated receptor gamma. J Biol Chem 278: 11945-11953, Epub 2003 Jan 27

Gupta RA, Tan J, Krause WF, Geraci MW, Willson TM, Dey SK, DuBois RN (2000) Prostacyclin-mediated activation of peroxisome proliferatoractivated receptor delta in colorectal cancer. Proc Natl Acad Sci USA 97: $13275-13280$

Han S, Inoue H, Flowers LC, Sidell N (2003) Control of COX-2 gene expression through peroxisome proliferator-activated receptor gamma in human cervical cancer cells. Clin Cancer Res 9: 4627-4635

Hanahan D, Weinberg RA (2000) The hallmarks of cancer. Cell 100: $57-70$

Hisatake JI, Ikezoe T, Carey M, Holden S, Tomoyasu S, Koeffler HP (2000) Down-regulation of prostate-specific antigen expression by ligands for peroxisome proliferator-activated receptor gamma in human prostate cancer. Cancer Res 60: 5494-5498

Ikezoe T, Miller CW, Kawano S, Heaney A, Williamson EA, Hisatake J, Green E, Hofmann W, Taguchi H, Koeffler HP (2001) Mutational analysis of the peroxisome proliferator-activated receptor gamma gene in human malignancies. Cancer Res 61: 5307-5310

Jacobs IJ, Menon U (2004) Progress and challenges in screening for early detection of ovarian cancer. Mol Cell Proteomics 3: 355-366, Epub 2004 Feb 5

Jaeckel EC, Raja S, Tan J, Das SK, Dey SK, Girod DA, Tsue TT, Sanford TR (2001) Correlation of expression of cyclooxygenase-2, vascular endothelial growth factor, and peroxisome proliferator-activated receptor delta with head and neck squamous cell carcinoma. Arch Otolaryngol Head Neck Surg 127: $1253-1259$

Jiang WG, Douglas-Jones A, Mansel RE (2003) Expression of peroxisomeproliferator activated receptor-gamma (PPARgamma) and the PPARgamma co-activator, PGC-1, in human breast cancer correlates with clinical outcomes. Int J Cancer 106: $752-757$

Kelly D, Campbell JI, King TP, Grant G, Jansson EA, Coutts AG, Pettersson S, Conway S (2004) Commensal anaerobic gut bacteria attenuate inflammation by regulating nuclear-cytoplasmic shuttling of PPARgamma and RelA. Nat Immunol 5: 104-112, Epub 2003 Dec 21

Kersten S, Desvergne B, Wahli W (2000) Roles of PPARs in health and disease. Nature 405: $421-424$

Kliewer SA, Forman BM, Blumberg B, Ong ES, Borgmeyer U, Mangelsdorf DJ, Umesono K, Evans RM (1994) Differential expression and activation of a family of murine peroxisome proliferator-activated receptors. Proc Natl Acad Sci USA 91: 7355-7359

Lambe KG, Tugwood JD (1996) A human peroxisome-proliferator-activated receptor-gamma is activated by inducers of adipogenesis, including thiazolidinedione drugs. Eur J Biochem. 239: 1-7

Lefebvre AM, Chen I, Desreumaux P, Najib J, Fruchart JC, Geboes K, Briggs M, Heyman R, Auwerx J (1998) Activation of the peroxisome proliferator-activated receptor gamma promotes the development of colon tumors in C57BL/6J-APCMin/+ mice. Nat Med 4: 1053-1057

Leung WK, Bai AH, Chan VY, Yu J, Chan MW, To KF, Wu JR, Chan KK, Fu YG, Chan FK, Sung JJ (2004) Effect of peroxisome proliferator activated receptor gamma ligands on growth and gene expression profiles of gastric cancer cells. Gut 53: $331-338$

Moras D, Gronemeyer H (1998) The nuclear receptor ligand-binding domain: structure and function. Curr Opin Cell Biol 10: 384-391

Mueller E, Smith M, Sarraf P, Kroll T, Aiyer A, Kaufman DS, Oh W, Demetri G, Figg WD, Zhou XP, Eng C, Spiegelman BM, Kantoff PW (2000) Effects of ligand activation of peroxisome proliferator-activated receptor gamma in human prostate cancer. Proc Natl Acad Sci USA 97: 10990-10995

Park BH, Vogelstein B, Kinzler KW (2001) Genetic disruption of PPARdelta decreases the tumorigenicity of human colon cancer cells. Proc Natl Acad Sci USA 98: 2598-2603

Pignatelli M, Cocca C, Santos A, Perez-Castillo A, Jiang WG, Douglas-Jones A, Mansel RE (2003) Enhancement of BRCA1 gene expression by the peroxisome proliferator-activated receptor gamma in the MCF-7 breast cancer cell line. Oncogene 22: $5446-5450$

Roberts-Thomson SJ, Snyderwine EG (2000) Characterization of peroxisome proliferator-activated receptor alpha in normal rat mammary gland and 2-amino-l-methyl-6-phenylimidazo[4, 5- $b]$ pyridine-induced mammary gland tumors from rats fed high and low fat diets. Toxicol Lett 118 $79-86$

Sato H, Ishihara S, Kawashima K, Moriyama N, Suetsugu H, Kazumori H, Okuyama T, Rumi MA, Fukuda R, Nagasue N, Kinoshita Y (2000) Expression of peroxisome proliferator-activated receptor (PPAR)gamma in gastric cancer and inhibitory effects of PPARgamma agonists. $\mathrm{Br} J$ Cancer 83: $1394-1400$

Seo JB, Moon HM, Kim WS, Lee YS, Jeong HW, Yoo EJ, Ham J, Kang H, Park MG, Steffensen KR, Stulnig TM, Gustafsson JA, Park SD, Kim JB (2004) Activated liver X receptors stimulate adipocyte differentiation through induction of peroxisome proliferator-activated receptor gamma expression. Mol Cell Biol 24: 3430-3444

Silverberg S (2000) Histopathologic grading of ovarian carcinoma: a review an proposal. Int J Gynecol Pathol 19: 7-15

Smith MR, Kantoff PW (2002) Peroxisome proliferator-activated receptor gamma (PPargamma) as a novel target for prostate cancer. Invest New Drugs 20: $195-200$

Terashita Y, Sasaki H, Haruki N, Nishiwaki T, Ishiguro H, Shibata Y, Kudo J, Konishi S, Kato J, Koyama H, Kimura M, Sato A, Shinoda N, Kuwabara Y, Fujii Y (2002) Decreased peroxisome proliferator-activated receptor gamma gene expression is correlated with poor prognosis in patients with esophageal cancer. Jpn J Clin Oncol 32: 238-243 
Theocharis S, Kanelli H, Politi E, Margeli A, Karkandaris C, Philippides T, Koutselinis A (2002) Expression of peroxisome proliferator activated receptor-gamma in non-small cell lung carcinoma: correlation with histological type and grade. Lung Cancer 36: 249-255

Tong BJ, Tan J, Tajeda L, Das SK, Chapman JA, DuBois RN, Dey SK (2000) Heightened expression of cyclooxygenase-2 and peroxisome proliferatoractivated receptor-delta in human endometrial adenocarcinoma. Neoplasia 2: $483-490$

Wang C, Pattabiraman N, Zhou JN, Fu M, Sakamaki T, Albanese C, Li Z, Wu K, Hulit J, Neumeister P, Novikoff PM, Brownlee M, Scherer PE, Jones JG, Whitney KD, Donehower LA, Harris EL, Rohan T, Johns DC, Pestell RG, Jiang WG, Douglas-Jones A, Mansel RE (2003) Cyclin D1 repression of peroxisome proliferator-activated receptor gamma expression and transactivation. Mol Cell Biol 23: 6159-6173

Yang Z, Bagheri-Yarmand R, Balasenthil S, Hortobagyi G, Sahin AA, Barnes CJ, Kumar R (2003) HER2 regulation of peroxisome proliferatoractivated receptor gamma (PPARgamma) expression and sensitivity of breast cancer cells to PPARgamma ligand therapy. Clin Cancer Res 9: $3198-3203$

Yoshimura R, Matsuyama M, Segawa Y, Hase T, Mitsuhashi M, Tsuchida K, Wada S, Kawahito Y, Sano H, Nakatani T (2003) Expression of peroxisome proliferator-activated receptors (PPARs) in human urinary bladder carcinoma and growth inhibition by its agonists. Int $J$ Cancer 104: $597-602$ 